\title{
COLLABORATIVE LEARNING TO ENHANCE ARABIC SPEECH SKILLS AMONG STUDENTS OF BACHELOR'S DEGREE (ISM) IN ARABIC LANGUAGE WITH EDUCATION AT SULTAN IDRIS EDUCATION UNIVERSITY
}

\author{
Saipolbarin Ramli ${ }^{1 *}$, Nor fatihah Ramli ${ }^{1}$, Mohammad Taufiq Abdul Ghani ${ }^{1}$, Wan Ab Aziz Wan Daud ${ }^{2}$, \\ Nazri Atoh ${ }^{1}$ \\ Faculty of Languages \& Communication, Sultan Idris Education University, Tanjung Malim Perak, Malaysia ${ }^{1}$ \\ Center for Language Studies and Generic Development, University of Malaysia Kelantan, Campus of Pengkalan Chepa, 16100, \\ Kota Bharu, Kelantan, Malaysia ${ }^{2}$ \\ *Corresponding author: saipolbarin@fbk.upsi.edu.my
}

\begin{abstract}
Collaborative learning refers to learning activities that involve two or more people who learn something together. This learning requires no teacher supervision and is not structured. This is the opposite to the cooperative learning where the role of the teacher as facilitator is to structure and monitor group activities to achieve their objectives. This study aimed to identify the issues faced by the students of bachelor's degree (ISM) in Arabic Language with Education at Universiti Pendidikan Sultan Idris (UPSI) to master Arabic speaking skills. This study also aimed to analyze the effectiveness of collaborative learning to enhance speaking skills and to analyze the degree of differences in the speaking skills before and after the implementation of collaborative learning. This quantitative study used a questionnaire and diagnostic test involving 29 Arabic language student respondents of the second semester in UPSI. In addition to conducting field studies, this study also made references to books, journals and theses on speaking skills and collaborative learning. The findings showed that collaborative learning methods could help students improve their proficiency in speaking Arabic. The results of this study are expected to have a positive impact and contribute to the teaching pedagogy of Arabic speaking skills for non-native speakers.
\end{abstract}

Keywords: Arab Language, speaking skills, collaborative learning, Universiti Pendidikan Sultan Idris Article Received: 18 October 2020, Revised: 3 November 2020, Accepted: 24 December 2020

\section{Introduction}

Looking at the Arabic language in the Malaysian context, the data indicate that Arabic is taught in Malaysia as it is a language learned for the sake of religious demand. In addition, the Arabic language curriculum in Malaysia is also more rigid and static and focuses on stereotypical teaching such as the teachings of nahu and balagah (Saipolbarin et al., 2017, Mohammad Taufiq et al., 2017). This situation results in students losing interest to learn Arabic (Abdul Hakim Abdullah et al., 2016). There are also allegations that label Arabic as a nonscientific language (Zainudin, 2018). This study aims to open a new scope of Arabic language teaching and learning (PdP) activities in Malaysia to prepare for teacher resources in teaching Arabic language subjects by adopting a student-centered learning approach. This description indirectly provides students with a wealth of experience and opportunities to participate in PdP activities in the classroom, in line with the Teaching and Learning 4.0 (PdP 4.0) concept (Al Muhsin \& Ahmad, 2019).

The focus of this study was to look at the problems in mastering the speaking skills among the students of ISM in Arabic Language with Education, which involved 29 student respondents. A cooperative learning approach was introduced to students as an alternative method in PdP activities. At the same time, it might help students to master the speaking skills in Arabic more effectively. This study involved two stages. The first stage was to analyze the problems in mastering the speaking skills among students. The second stage was to develop 
and implement a cooperative learning module for Arabic speaking skills (Al Muhsin et al., 2020). The study corpus involved 29 students of ISM in Arabic Language with Education, UPSI. The research instruments included questionnaires, pretest and post-test.

According to Noor Hisham Md. Nawi (2011), teaching activities are assignments and activities in which teachers and students work together. Without one of them, teaching would not have happened. Learning can happen anywhere and anytime. Learning requires methods and processes ranging from simple to complex ones (Noor Hisham Md. Nawi, 2011). In the Arabic language learning activity for non-speakers, there are four basic language skills that students need to master, two of which (reading and listening) are premier skills and the other two (writing and speaking skills) are secondary skills. Both of these groups of skills need to be properly integrated for planning appropriate activities in the PdP (Saipolbarin et al., 2017). However, this study only focused on Arabic speaking skills. This is because speaking is a difficult skill for students to master compared to listening, writing and reading skills. This statement is supported by Bailey (2005) who says that many who learn a certain language find that the skills of speaking the language that they learn is more difficult than other skills.

In this study, collaborative learning was used by the researchers to improve speaking skills. Collaborative learning refers to group learning activities for the purpose of achieving learning objectives. Yahya Othman (2009) defines collaborative learning as a situation that requires students to form small groups and work together as a team to help each other in their learning. Usually, students will carry out activities in groups of two or more, seeking mutual understanding, solving or creating a learning outcome. This collaborative learning can be used to enhance Arabic speaking skills in PdP activities in schools. At the end of this study, a cooperative learning module is proposed to be applied in Arabic language teaching at the university level. It is hoped that this alternative method will contribute to Arabic language pedagogy in an effort to sustain Arabic language education in Malaysia.

\section{Study Objectives}

1. To identify the obstacles faced by students in speaking Arabic well.

2. To analyze the effectiveness of collaborative learning in improving speaking skills.

3. To analyze the difference in the level of speaking skills before and after implementing collaborative learning.

\section{Study Problems}

Researchers have found that the problems faced by the students in regard to Arabic speaking skills were a major problem for the students. This is because students have been learning Arabic for a long time, probably since primary or secondary school to higher education, but they are still unable to master the Arabic language, especially in the speaking skills. According to Naimah and Aini (2005), even though third language students receive formal learning at school level, they still have difficulty communicating in the Arabic language that they are learning. Ab. Halim (2007) states that the proficiency in Arabic among students of public higher learning institutions specializing in Arabic language, do not achieve good language proficiency. Therefore, this study has been conducted to improve the speaking skills of the second semester students at UPSI.

\section{Literature Review}

Arabic language education at secondary schools focuses more on communication by placing speaking skills as the second skills after listening skills (Wizarah Tarbiyyah Maliziyyah, 2003). Nik Mohd. Rahimi (2000) mentions that the Arabic language curriculum emphasizes more on listening and speaking skills in addition to two other skills, namely reading and writing. This past study shows that speaking skills among students is the most important as it facilitates us to speak Arabic. There have been many studies on the speaking skills, which is a problem with speaking Arabic among 
students especially in the higher learning institutions. The main factor that makes students unable to speak Arabic is because of their lack of vocabulary. This finding is in line with a study conducted by (Gan, 2012) saying that lack of vocabulary is a major factor that hinders communication processes and causes students to fail to speak fluently and fail to communicate clearly. This is because, one of the ways students can speak Arabic well is to memorize many Arabic vocabulary. In addition, self-confidence is also needed in order to be able to speak Arabic well. Zarima \& Taj Rijal (2008) explain that most students are weak in speaking and writing and lack of confidence in speaking Arabic.

In improving Arabic speaking skills, we should use learning strategies that are in line with that education or skills. According to Sueraya et.al (2010) in her study at UIAM, she found that other factors contributing to this problem were lack of awareness of the language learning strategy (SPB) of Arabic speaking skills. In addition, the unhelpful environment and the lack of opportunities to speak Arabic are also contributing factors (Al Muhsin et al., 2020). Therefore, researchers use collaborative learning to improve Arabic speaking skills among UPSI students. This is because collaborative learning can help students work together in groups.

According to Schrage in Mumtaz Begam Abdul Kadir (2009), collaborative learning is more than a work together activity, as it involves the sharing of findings and outcomes obtained from a new lesson. Therefore, when studying in a group, students can also share information or opinions with their peers while also improving their Arabic language skills as students will become more active when they learn using collaborative learning. This is related to a study by (Amierul Akmal and Azean, 2014) that collaborative learning supports students to help one another during a $\mathrm{P} \& \mathrm{P}$ process and indirectly communicate with one another. Collaborative learning is one of the effective learning strategies for improving Arabic speaking skills among students. According to Tham and Tham (2013), collaborative learning is one of the most effective learning strategies in developing communication skills for students.

\section{Methodology}

\subsection{Study Limitations}

This study was conducted at Universiti Pendidikan Sultan Idris involving the second semester Arabic Language students. The study involved 29 students of the second semester of Arabic Language consisting of 5 male students and 24 female students.

\subsection{Instruments}

A descriptive design was used for this study, which is a procedure for measuring and interpreting quantitative data. For data collection, this study used 2 sets of questionnaires as its instruments. The questionnaire consisted of 2 parts. Part A is about the background of the respondents. Part B provides the data for the study objectives. In this study, the researchers used the Likert Scale to obtain answers from the respondents. There were three possible answers, namely agree, not sure and disagree. This questionnaire was distributed to the respondents through goggle form after being validated by DR. Saipol Barin Bin Ramli. In addition, two oral tests were also conducted for the students to obtain data. Then, a data analysis process was carried out to get a simple percentage. The researchers presented the data using bar graphs and pie charts and analyzed the data using percentages in google form.

\section{Study Findings}

\subsection{Students' Problems in Arabic Speaking}

The findings of this study were analyzed based on the content of the questionnaire and based on the objective, which was to identify the problems faced by the students in mastering the Arabic language skills. There were eight issues related to the problems in mastering the Arabic language skills as shown in Table 1. 
Table 1. Students' Problems in Mastering Arabic Speaking

\begin{tabular}{l|llll}
\hline NO. & DESCRIPTION & \multicolumn{3}{l}{ RESPONSE } \\
& & Disagree & Not Sure & Agree \\
\hline 1 & I always speak Arabic with friends. & $16(55 \%)$ & $13(45 \%)$ & $0(0 \%)$ \\
2 & I feel shy to speak Arabic with my friends. & $9(31 \%)$ & $7(24 \%)$ & $13(45 \%)$ \\
3 & I do not have the confidence to speak Arabic. & $8(28 \%)$ & $7(24 \%)$ & $14(48 \%)$ \\
4 & I do not have friends to speak Arabic with. & $15(52 \%)$ & $2(7 \%)$ & $12(41 \%)$ \\
6 & I do not speak Arabic because of the lack of & $1(4 \%)$ & $4(13 \%)$ & $24(83 \%)$ \\
7 & vocabulary. & & & \\
8 & I am not given the opportunity to speak Arabic. & $18(62 \%)$ & $3(10 \%)$ & $8(28 \%)$ \\
9 & I have low self-esteem to speak Arabic. & $11(39 \%)$ & $1(4 \%)$ & $16(57 \%)$ \\
10 & I am afraid my friends will laugh at me if I speak & $8(28 \%)$ & $8(28 \%)$ & $13(44 \%)$ \\
& Arabic. & & & \\
& I am not motivated to speak Arabic. & $10(35 \%)$ & $8(28 \%)$ & $11(37 \%)$
\end{tabular}

Based on the table above, the findings of this study clearly show the obstacles to speak Arabic well faced by students. The main obstacle for students to speak Arabic well was due to the lack of vocabulary in which 24 students $(83 \%)$ agreed, while 4 students (13\%) and 1 student (4\%) disagreed on that. This finding is in line with a study conducted by (Gan, 2012) who says that lack of vocabulary is a major factor that hinders communication processes and causes students fail to speak fluently and fail to convey message clearly. This means that lack of vocabulary is not only experienced by UPSI semester 2 Arabic students but also by other students. The next obstacle that caused students unable to speak Arabic well was because students had a low selfesteem to speak Arabic. Of which 16 students
(57\%) agreed, while one student (4\%) was uncertain and 11 students (39\%) disagreed. Then the next obstacle is students lack confidence in speaking Arabic. 14 students (48\%) agreed, while 7 students $(24 \%)$ were not sure and 8 students (28\%) disagreed. In this context, students feel frustrated, lacking confidence, afraid and shy when they made mistakes in speaking the language (Ashinida, 2012). In conclusion, these three obstacles are common obstacles faced by all students in speaking Arabic well.

\subsection{Collaborative Learning Helps to Improve Speaking Skills}

This section aims to achieve the second objective which is to analyze collaborative learning in helping to improve speaking skills. The data is shown as in Table 2.

Table 2.0 Students' Knowledge of the Concept of Cooperative Learning

\begin{tabular}{|c|c|c|c|c|}
\hline \multirow[t]{2}{*}{ NO. } & \multirow[t]{2}{*}{ DESCRIPTION } & \multicolumn{3}{|c|}{ RESPONSE } \\
\hline & & 1 & 2 & 3 \\
\hline 1 & $\begin{array}{l}\text { I understand the concept \& definition of } \\
\text { collaborative learning. }\end{array}$ & $0(0 \%)$ & $8(28 \%)$ & $21(72 \%)$ \\
\hline 2 & $\begin{array}{l}\text { I apply collaborative learning strategies with } \\
\text { friends. }\end{array}$ & $0(0 \%)$ & $7(24 \%)$ & $22(76 \%)$ \\
\hline 3 & $\begin{array}{l}\text { I am interested in using collaborative learning to } \\
\text { improve my Arabic speaking skills. }\end{array}$ & $0(0 \%)$ & $4(14 \%)$ & $25(86 \%)$ \\
\hline 4 & $\begin{array}{l}\text { Collaborative learning has helped me to actively } \\
\text { engage in speaking. }\end{array}$ & $0(0 \%)$ & $4(14 \%)$ & $25(86 \%)$ \\
\hline
\end{tabular}


5

6

7

8

9
Collaborative learning enhances my level of $0(0 \%) \quad 4(14 \%) \quad 25(86 \%)$ confidence in speaking Arabic.

Collaborative Learning can help me improve my $0(\%) \quad 5(17 \%) \quad 24(83 \%)$ nahu in Arabic.

Collaborative learning encourages me to speak $0(0 \%) \quad 4(15 \%) \quad 25(86 \%)$ Arabic.

Collaborative learning enables students to share $0(0 \%) \quad 3(10 \%) \quad 26(90 \%)$ opinions.

Speaking Arabic is easier when using collaborative $\quad 0(0 \%) \quad 3(10 \%) \quad 26(90 \%)$ learning.
Based on the table above, the findings of this study clearly show that collaborative learning helps to improve speaking skills among the second semester Arabic Language students. A total of 26 students (90\%) agreed that the statement of collaborative learning enables students to share opinions and speaking Arabic is easier when using collaborative learning. Meanwhile, 3 students $(10 \%)$ were not sure on the statement. When using this type of learning in Arabic language learning, students will communicate in Arabic within the group as well as create a sharing of ideas between students. Furthermore, collaborative learning can help students become actively engaged in speaking. A total of 25 students ( $86 \%$ ) agreed while 4 respondents (14\%) were unsure of the statement. Collaborative learning really helps students to engage in the activities provided. This statement is supported by (Amierul Akmal and Azean, 2014) that this collaborative learning supports students to help one another during the P\&P process and indirectly, they will communicate with one another. The majority of respondents agreed with the above statement that collaborative learning helped to improve their speaking skills. According to Tham and Tham (2013), collaborative learning is one of the most effective learning strategies in developing communication skills for students.

\subsection{Students' Achievement Levels of Speaking Skills in Pre And Post Implementation of Cooperative Learning}

This section aims to achieve the third objective, which is to analyze the different levels of speaking skills before and after implementing collaborative learning. The data is as shown in Table 3.

Table 3.0 Differences in Students' Achievement Levels in Pre and Post Implementation of Cooperative

Learning

\begin{tabular}{|l|l|l|l|}
\hline No & Grade & Pre Implementation & Post Implementation \\
\hline 1. & MUMTAZ & $1(3 \%)$ & $9(31 \%)$ \\
\hline 2. & MAQBUL & $0(0 \%)$ & $12(41 \%)$ \\
\hline 3. & JAYYID JIDDAN & $18(62 \%)$ & $7(25 \%)$ \\
\hline 4. & JAYYID & $8(28 \%)$ & $1(3 \%)$ \\
\hline 5. & RASIB & $2(7 \%)$ & $0(0 \%)$ \\
\hline
\end{tabular}

Based on the above table, respondents were tested with oral tests twice before, that is, before implementing collaborative learning and after performing collaborative learning. Respondents were given a title to speak Arabic and were given
10 minutes to speak. The differences between the two tests were not significant. Prior to conducting the collaborative learning, the mumtaz respondents were only one $(3 \%)$, jayyid with 18 respondents (62\%), jayyid jiddan with 8 respondents $(28 \%)$ and 
rasib with 2 respondents (7\%). There has been an increase in speaking skills after the implementation of collaborative learning.

The number of respondents who received mumtaz was 9 respondents (32\%), maqbul with 12 respondents (41\%), jayyid jiddan with 7 respondents $(25 \%)$ and jayyid with only one respondent. After implementing collaborative learning, there were no more respondents who failed the test. Therefore, collaborative learning is very helpful for students in developing Arabic speaking skills rather than self-learning. According to Amierul Akmal \& Azean (2014), there is a learning strategy that can enhance students' communication level as well as other skills during the P\&P process.

\section{Conclusion}

This study has explained that there were some obstacles for students to speak Arabic such as students with low vocabulary, students with low self-esteem to speak Arabic, students did not have the confidence to speak Arabic, and students were shy to speak Arabic and so on. These obstacles were the most dominant among all. Therefore, researchers have used collaborative learning to improve Arabic speaking skills of the students (Mumtaz Begam Abdul Kadir, 2009). A study has been conducted on the students to get the results from the use of collaborative Arabic learning. Based on the questionnaires, the students agreed that collaborative learning could create sharing of opinions among the students. Further, speaking Arabic was easier when using collaborative learning. In addition, based on the oral tests done to the students, this collaborative learning has helped to improve Arabic speaking skills among students.

This is because students' achievement in speaking skills has increased after using collaborative learning. This study confirms with the statement from Tham and Tham (2013) that collaborative learning is one of the most effective learning strategies in developing communication skills for students.

\section{References}

[1] Al Muhsin, M. A., Ahmad, N. Z., Sarudin, A., Muhammad, M. M., Othman, Z., Makki, S., \& Kassymova, G. K. (2020). The Implementation of SCL in Teaching Arabic for Islamic Finance: A Dynamic Approach in Preparing for Education 4.0. International Journal of Psychosocial Rehabilitation. Vol. 24(9), p. 279 - 290.

[2] Al Muhsin, M. A., Mohd, K. N., Muhammad, A. S., Osman, Z., Makki, S., \& Etigani, M. A. M. A. (2020). THE CHARACTERISTICS OF PROPOSE ARABIC LANGUAGE MODULE FOR THE PURPOSE OF TOURISM: A CASE STUDY ON TOURISTS'MOSQUE IN KUALA LUMPUR. Journal of Critical Reviews, 7(14),

515-521. http://dx.doi.org/10.31838/jcr.07.14.89

[3] Aladdin, A. (2012). Analisis penggunaan strategi komunikasi dalam komunikasi lisan Bahasa Arab. GEMA Online ${ }^{\circledR}$ Journal of Language Studies, 12(2).

[4] Bailey, K. M. (2005). Speaking. New York: McGraw-Hill.

[5] Begum, M. (2009). Learning organization: membentuk budaya belajar dalam organisasi. Kuala Lumpu: PTS Professional.

[6] Gan, Z. (2012). Understanding L.2 speaking problems: Implication for ESL Curicculum Development in a teacher Training Instituation in Hong Kong. Australian Journal of Teacher Educational. http://ro.ecu.edu.au/ajte/vol37/iss1/3

[7] Ghani, M. T. A., Ramli, S., \& Hamat, M. Z. A. (2019). Arabic Sentence Construction Among Sultan Idris Education University (UPSI) Students. al-Qanatir: International Journal of Islamic Studies, 15(1), 12-22.

[8] Haron, S. C., Ahmad, I. S., Mamat, A., \& Mohamed, I. H. A. (2010). Understanding Arabic-Speaking Skill Learning Strategies among Selected Malay Learners: A CaseStudy at the International Islamic University Malaysia 1859 
(IIUM). Contemporary Issues in Education Research, 3(8), 9-20.

[9] Mohamad, A. H. (2007). Masalah Komunikasi Bahasa Arab di Kalangan Pelajar Bacelor Bahasa Arab di IPTA Malaysia. In Prosiding Seminar Penyelidikan Dalam Pengajian Islam $\mathrm{Ke}$ (Vol. 4).

[10] Mohd Amerul Akmal dan Noor Azean (2014). Strategi Pembelajaran Kolaboratif dalam persekitaran autentik bagi pembentukan kemahiran proses sains asas prasekolah menerusi teknologi APPS. Universiti Teknologi Malaysia (UTM). Malaysia

[11] Muhsin, M. A. A., \& Ahmad, N. (2019). The Emergence of Education 4.0 Trends in Teaching Arabic Islamic Finance Curriculum Design: A Case Study. International Journal of Psychosocial Rehabilitation, 23(4).

[12] Naimah, A., \& Aini, A. (Cartographer). (2005). Kajian tentang persepsi pelajar UiTM terhadap kepentingan bahasa ketiga di UiTM.

[13] Nawi, N. H. M. (2011). Pengajaran dan pembelajaran: penelitian semula konsepkonsep asas menurut perspektif gagasan islamisasi ilmu moden. http://umkeprints.umk.edu.my/id/eprint/11 1

[14] Nik Mohd Rahimi Nik Yusoff. (2000). Tahap Kemahiran Bertutur Bahasa Arab antara Jantina, Latar Belakang Keluarga, Tahap Minat dan Pencapaian dalam Peperiksaan. Jurnal Pendidikan. Vol. 24, 141-154.

[15] Othman, Y., Baki, R., \& Mat, N. (2009). Pemerkasaan Pendidikan Bahasa Melayu dari teori ke praktik. Utusan Publications.

[16] Saipolbarin. Nazri Atoh. Zarima Mohd, Z., Mohammad Ariffin. (2017). I-Kit Bahasa Arab Dalam Kalangan Pelajar ISM Bahasa Arab dengan Pendidikan UPSI: Satu
Analisis. Journal of Global Business and Social Entrepreneurship, 03(7), 79-89.

[17] Tham, R., \& Tham, L. (2013). Learning Effectiveness of Collaborative Learning in Singapore Higher Education-A Pilot Study. In Society for Information Technology \& Teacher Education International Conference (pp. 1073-1090). Association for the Advancement of Computing in Education (AACE). https://www.learntechlib.org/primary/p/48 $261 /$

[18] Wizarah al-Tarbiyah al-Maliziyah. (2003). al-Manhaj al-Mutakamil li al-Madrasah alThanawiyah: al-Saff al-Awwal. Kuala Lumpur: DBP.

[19] Zainudin Maidin. (2018). Bahasa Arab Bukan Lagi Bahasa Sains Teknologi Dan Bidang Profesional. http://zamkata.blogspot.com/2018/07/baha sa-Arab-bukan-bahasa-sains.html.

[20] Zakaria, Z. M., \& Ramli, T. R. M. (2008). Sejarah perkembangan program minor bahasa Arab di Fakulti Bahasa UPSI. In Prosiding Seminar Pengajaran Bahasa dan kesusasteraan Arab di Institusi Pengajian Tinggi Malaysia. Jabatan Bahasa Arab dan Tamadun Islam, Fakulti Pengajian Islam, UKM pada (pp. 22-23). 